
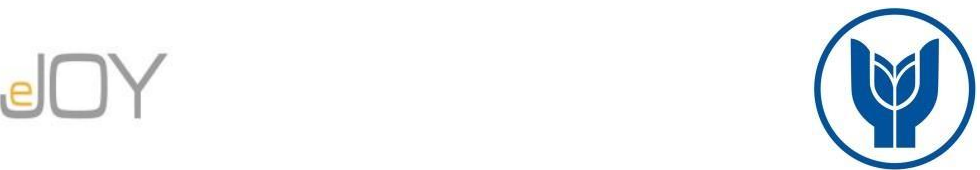

Kara, F. Z., Bilir, H. / Journal of Yasar University, 2021, 16/64, 1872-1886

\title{
Economics Education in Turkey: Places of The History of Economic Thought and Economic History Courses in The Curricula
}

\section{Türkiye'de İktisat Eğitimi: İktisadi Düşünce Tarihi ve İktisat Tarihi Derslerinin Müfredattaki Yerleri}

\author{
F. Zişan KARA, Aksaray Üniversitesi, Türkiye, fzkara@aksaray.edu.tr \\ Orcid No: 0000-0002-8938-6768 \\ Hüsnü BİLİR, Aksaray Üniversitesi, Türkiye, husnubilir@aksaray.edu.tr \\ Orcid No: 0000-0001-9602-8267
}

\begin{abstract}
Economics education has been progressing same as natural sciences such as physics and mechanics, estranged from disciplines such as history, ethics, philosophy, sociology, and psychology in contrast to the classical political economy, as its predecessor which has become the dominant doctrine in the discipline of economics since the early $20^{\text {th }}$ century. Organizing economics education with an emphasis on mathematics and econometrics, and estranging it from other social sciences deepen such a fundamental problem. It is seen that mathematical, statistical, and econometric methodologies loom large for economics education in Turkey, and it is possible to assert that other social sciences such as history, sociology, and philosophy are unable to find enough space in the economics curricula. This study aims to examine the economics curricula of universities established in Turkey and to determine the shares of courses such as the history of economic thought and economic history in the curricula.
\end{abstract}

Keywords: Economics Education, History of Economic Thought, Economic History, Neoclassical Economics

JEL Classificiation: A12, A22, A23

Öz: İktisat ĕgitimi özellikle yirminci yüzyılın başlarından itibaren iktisat disiplinindeki hâkim öğreti haline gelen neoklasik iktisat aracılı̆̆ ile halefi olduğu klasik ekonomi politiğin aksine, tarih, etik, felsefe, sosyoloji, psikoloji gibi disiplinlerden uzaklaşarak, fizik ve mekanik gibi doğa bilimlerini kendisine örnek alarak ilerlemektedir. İktisat eğitimini matematik ve ekonometri ă̆ırlıklı organize etmek ve diğer sosyal bilim alanlarından uzaklaştırmak bu temel problemi derinleştirmektedir. Türkiye'de iktisat eğitiminde matematiksel, istatistiksel ve ekonometrik yöntemlerin ön planda olduğunu ve tarih, sosyoloji, felsefe gibi diğer sosyal bilim alanlarının iktisat müfredatında yeterince yer bulamadı̆̆ını söylemek mümkün görünmektedir. Bu çalışmanın amacı, Türkiye'deki üniversitelerin iktisat müfredatlarını incelemek ve iktisadi düşünce tarihi, iktisat tarihi gibi derslere müfredatlarda ne kadar yer ayrıldı̆̆ııı tespit etmektir.

Anahtar Kelimeler: İktisat Eğitimi, İktisadi Düşünce Tarihi, İktisat Tarihi, Neoklasik İktisat

JEL Siniflandırmast: A12, A22, A23

\section{Introduction}

Economics education is, in general, driven towards explicating the decisions of individuals and societies in fulfilling unlimited human needs with limited resources as well as the reasons, impacts, and effectiveness of such decisions. The undergraduate program in the departments of economics aims to provide students with a solid theoretical background in their fields of study and to support this effort with econometric and statistical methods and analysis within the applied domains. The main purpose of this program is to confer a broad perspective on the students regarding their approach to real-life economic events and issues in acquiring the ability Makale Gecmiși / Article History 
to apply current analytical instruments to solve these problems (Şimşek \& Cicioğlu, 2007: 18). In the graduate education programs, training scientists and contribution to the implementation of national science policy are considered as the leading targets. The aim of the master's program with thesis is stated by the Postgraduate Education Regulation as to enable the students to gain the ability to access information, evaluate and interpret information by conducting scientific research studies, and the purpose of the doctoral program is to carry out independent research studies to examine scientific events with a broad and deep perspective, to interpret the obtained results, and to acquire the ability to determine the necessary steps to achieve new syntheses (Yılmaz, Tonga, \& Çakır, 2017: 3).

Upon examining the literature on economics education, it is seen that there is no systematic approach in the determination of undergraduate and graduate courses in economics education and that the courses lectured at the undergraduate level are mostly arranged to contribute to the teaching of mainstream economics - in this way, alternative economic approaches are not included. Considering that undergraduate and graduate degrees have different goals, it would be uncertain whether economics education aims to provide a profession or to contribute to the production of scientific knowledge by teaching economic thought. Despite the fact that economics education is unilaterally conducted in terms of neoclassical economics as the contemporary predominant economic approach, it does not seem possible to avoid the question of how economics should be? upon emphasizing the extent to which economics education should be. In this context, the aim of the study is not to question economics within the scope of a methodological approach, but to reveal the weight of the courses lectured in economics education. This study aims to investigate both undergraduate and graduate-level economics education within the framework of core and elective economics courses lectured in education programs offered by the state and foundation universities established in Turkey during the Academic Year 2019-2020. In this context, it is tried to determine whether economics education has a relatively standardized structure under the domination of mainstream economics, or aims at contributing to the production of knowledge from a wider economic perspective of economics in association with other social sciences.

\section{Basic Arguments in Economics Education}

Studies on the extent to which economics education should have been progressed with the effort of economics to find a place in the world of science. Studies conducted on this issue may date far back to H.R. Seager's seminal work entitled “Economics at Berlin and Vienna” published in the Journal of Political Economy as of 1893. Seager, concerning the comparison of the 
economics education offered in Berlin and Vienna in terms of by whom and how many hours per week the courses were taught, argued that economics education should have been received in Vienna if it was desired to deal with topics such as general economic theory, the development of economic theory, and general equilibrium, whereas in Berlin if there was more focus on social issues and economic history (Seager, 1893: 262). In this regard, it can be claimed that economics education had been subject to a distinction as of the $19^{\text {th }}$ century.

In the discussions on economics education, the basis of the discussion is closely related to the response to be given to the question of where the graduates of economics departments would be guided/directed following the graduation. One might ask whether it is aimed at guiding the graduated students only toward performing certain tasks in various institutions and organizations through economics education, or it is aimed at rendering the graduate students adequately equipped with the potential in contributing to the knowledge of society in this sense, and in following the views and models that try to explain the changes in the world economy, in general, as well as the dynamics that cause such changes (Süalp, 2012: 4).

In this regard, although economics education is considered within the framework of determinants of students' success in the Introduction to Economics courses in some studies ${ }^{1}$ (Watts \& Lynch, 1989; Anderson, Benjamin \& Fuss, 1994; Tay, 1994; Douglas \& Sulock, 1995; Kherfi, 2008), economics education usually involves market requirements and the extent to which the financial system should be formed in compliance with these requirements (Cyert, 1984; Hyslop-Margison, 2000; Santomero, 2003). It can be said that such a situation arises from the fact that neoclassical economics has become the predominant school of economic thought within the scope of economics education ${ }^{2}$, the neoclassical approach has transformed into a type of academic notion especially in university education since the Second World War, and economics education has been formed in line with this domination (Blaug, 1998; Nelson, 2001; Sent, 2006).

In this sense, perhaps the most crucial problem encountered by economics education is the standardization of knowledge in the relevant field. According to Süalp (2012), the standardization of knowledge unilaterally determines the degree of importance of the problems and questions in that field on the one hand, and on the other hand, it ignores the context and historical process through which these problems and questions arise, as well as the blockages and shortcomings for which they were proposed as solutions. In analyzing the economic

\footnotetext{
${ }^{1}$ For studies suggesting that economics education changes the students' point of view and renders them particularly more selfish and greedy, see. Frank et al., 1993, 1996; Frey et al., 1993; Wang, Malhotra and Murnighan, 2011.

${ }^{2}$ For a detailed analysis of conceptual transition from political economy to economics see. Üşür, 2003.
} 
activities of social life, which is an extremely complex organism, the unilateral determination of the questions and problems and the transmission of these as "the only correct knowledge" along with the models of a standard information package, accompanies the training of educated people as a technician, a social engineer rather than having a scientific background. Because the technical level included in the standardized knowledge surpasses the scientific quality of such knowledge for its buyers. Basic curricula in economics education, comprised of the micro and macro theory courses, have almost universally standard features including "applied" courses built on both micro and macro foundations designed to complement those courses (Stilwell, 2006: 44). Accordingly, textbooks are created by adapting the standard textbooks of the leading figures of economics such as Samuelson and Nordhaus (1998), Mankiw (2005), and Stiglitz (2006). In almost all textbooks, the basic problems that an economy would encounter what to produce, how to produce, and for whom to produce - are discussed, and figures illustrating the relationship between households and the business world in a market economy are introduced (Kern, 1990: 196).

In the study entitled "The Assessment of Higher Education Learning Outcomes (2011)" prepared by the OECD, the standardization of economics education is expressed as follows:

In the curricula of universities around the world, there is not only a consensus on what it means to think like an economist, but there is also a consensus on the type of courses or subjects required to have an economic way of thinking. (OECD, 2011: 4)

In this framework, it can be claimed that programs and curricula are prepared similarly, and more importantly, the textbooks used in economics are ultimately the same (Brückner et al., 2015: 439). The economics curricula are largely in compliance with defined standards such as the internationally accepted K-12 National Content Standards for Economic Education (CEE, 2010) prepared for the USA (Kuhn et al., 2018: 26). CEE's (2010) content standards for economics education are determined as scarcity, decision-making, distribution, incentives, trade, specialization, markets and prices, the role of prices, competition and market structure, institutions, money, and inflation, interest rates, income, entrepreneurship, economic growth, the role of government and market failure, government failure, economic fluctuation, unemployment and inflation, fiscal and monetary policy. It is stated that these standards concentrate on the basic economic ideas and concepts widely shared by professional economists and that the textbooks used by teaching staff are generally prepared in accordance with these standards, these standards are used upon preparing curricula, and that researchers also benefit from these standards while establishing the conceptual framework for their studies (CEE, 2010, p. vii-viii). 
This comprehension of economics is presented to students as a way of apprehending the essentially timeless economic principles that shape the world (Stilwell, 2006). As a result of such comprehension, the students turn into a passive audience that cannot associate the theoretical education offered to them with the actual life (Aydin, 2016: 43). Shiller (2010) emphasized the distinction between theoretical economics education and practical, up-to-date economics education as an element of tension in economics education. Another tension in economics education involves the idea that the models taught to students are abstractions that remain within the scope of the course and would have neither an impact nor contribution to their practical lives.

Therefore, it can be said that the pluralism in discourse has disappeared, especially following the Second World War, along with the increasing domination of neoclassical economics (Blaug, 1999, 2003; Dow, 2009). In this direction, heterodox economics have been excluded from the economic programs in the USA and they are being pushed out of the programs more and more both in Europe and Latin America (Colander, Holt and Rosser, 2010: 407). In this context, other schools of economic thought other than neoclassical economics are excluded from the curricula and courses such as the history of economic thought, economic history, economic sociology, philosophy of science, philosophy of science, and economic psychology are also ignored.

It has been frequently stated following the crisis of $2007-2008^{3}$ that such standardization in economics education must change (Ramsden, 2012; Mearman, Berger, \& Guizzo, 2016). In fact, it has been suggested that a similar situation was experienced in the first half of the $20^{\text {th }}$ century and economics education should have been changed as a result of the economic, social, and cultural changes experienced after the Great Depression of 1929 (Matherly, 1935). In this direction, there should be topics from other social science domains such as sociology, psychology, political science, anthropology, and history in economics education (Uygur, 2012: 19). Nonetheless, besides the economics departments that establish closer ties with social sciences in which the student can acquire a better understanding of the institutions of the economy, the history, as well as the world and society to which they belong; economics departments that would give more weight to quantitative methods may also be designed (Sunal, 2017: 37). In this context, the study of the history of economic thought is held in low-esteem

\footnotetext{
${ }^{3}$ The one-sidedness of economics education, due to its presentation as if there was only a single method of economic thinking, draws attention as a phenomenon that lead to increasing discomfort even among the doctoral students at universities that are considered to offer the best economics education in the world (Süalp, 2012: 2-3). The student movement, also known as the post-autistic economics, can be considered as a reflection of the global dissatisfaction toward the one-sidedness of economics education.
} 
by mainstream economists especially since the end of World War II and its virtual disappearance from university curricula both at the graduate and the undergraduate levels (Blaug, 2001: 145).

\section{Importance of the History of Economic Thought and the Economic History}

It is asserted that economics education and therefore economics courses should be designed in a way that "teaches students to think like economists" (Mankiw, 2005; Wunder, Kemp, \& England, 2009). David Colander argued that individuals were not born as economists and that the process of both formal and informal education received by economists would form their attitudes toward problems, the way they handle knowledge, and their fields of study (Aysan, Hacihasanoğlu, Kara, \& Suner, 2006: 1).

In this respect, examining the history of any discipline may provide enlightening information on how this branch of science has come to this day, what stages it has gone through, which theoretical, practical, and institutional obstacles have been encountered throughout these stages (Kurmuş, 2009: 49). Also, students would understand that economics discipline consists of various perspectives and schools of thought.

For this purpose, the history of economic thought or economic philosophy should not be taught to a third- or fourth-year economics student as if it was a relatively insignificant course independent from other courses, and these courses should be lectured in the freshman years of economics departments as a basic course and in a comprehensive way to include different economic schools comparatively. Because if the student learns about the development of economic thought, the existence of different schools of economic thought, the extent to which the economic philosophy was formed in different schools in advance, he/she would be able to perceive much more easily that the economics education that she would receive in advanced classes is not the only teaching available and that different results would arise in different situations with different conditions (Ruben, 2001: 37). Because only in the history of economic thought course, students study the alternative schools of thought and heterodox schools of thought outside the mainstream, the economists such as Marshall, Knight, Keynes, Marx, Veblen, Hayek, Schumpeter as well as the close relationship between other social sciences and economics (Blaug, 2001; Caldwell, 2013).

According to Schumpeter (1954: 4-6), the history of economic thought was essential since the historical process had been indispensable for students to acquire a comprehensive knowledge of economics and to diversify the way students think by presenting information regarding the human mind. Boot (1997: 159), on the other hand, stated that the economic history 
and the history of economic thought enabled students to evaluate the most appropriate implications of historical facts, thus improved their cognitive abilities as well as their abilities to apply what they learned to real issues and institutional structures.

McCloskey (1976) argued primarily that history had pragmatic benefits for economics. History provided us with more economic information and observation. It also enabled us to achieve more qualified economic information. Because historical information was not obtained only by economists. Many disciplines retrieved information from the pages of history that may shed light on economic life. For instance, realizing that people and companies were mortal also in the 18th century might make economists notice that the issues they have studied do not merely belong to the last decade. The second and equally important reason for the study of economic history was an intellectual concern (Aysan \& Ulu, 2013: 6).

Süalp (2012) stated that, in order to inform and motivate especially the freshman students regarding the problems with which the field has been dealing, the whole freshman year should consist of only a comprehensive economic history in relation to economics, besides mathematics, statistics, and other "extracurricular" courses. He emphasized that various concepts such as supply-demand, interest rate, etc. should have been introduced in such a historical perspective, and argued that such a method would have been an important start in differentiating economics education from being an outdated and memoryless knowledge transfer process.

In this direction, there are efforts to create a more pluralistic approach in economics education. For instance, according to Barone (1991), the Department of Economics at Dickinson College in the USA revised the economics curriculum as of 1984. Prior to this date, the basic curriculum of the department, with two heterodox lecturers out of the six existing lecturers, was mainstream, and the students would not have learned about heterodox economics, hence different perspectives, unless they elected the courses of the heterodox lecturers, and therefore the neoclassical economics would have constituted almost $80 \%$ of their school life. In this context, firstly, the economic history and the history of economic thought have begun to be lectured, and in 1987, the course entitled "Conflicting Economic Perspectives" was rendered compulsory. The aim was to examine the historical origins of schools of economic thought and familiarize students with different and often conflicting economic perspectives. Similarly, in South Korea, the economic history is a core course in some universities, along with the courses such as statistics, principles of microeconomics, and macroeconomics (Hahn \& Jang, 2010: 443). 


\section{Economics Education in Turkey}

The first study on economics education in Turkey, entitled "On Economics Education in Turkey" was conducted by Prof. Dr. Tuncay Bulutay and published in the Journal of the Faculty of Political Sciences as of 1965. Mainstream economics education in Turkey had begun to be conducted as of the 1960s by young economist lecturers.

Eren and Şahin (2008) emphasized that economics programs were increasingly similar in economics education and stated that the economic history and the history of economic thought were offered as core courses in all economics departments providing education in the Turkish language, and as an elective course in some departments providing education in foreign languages. This situation arising from the decline in the importance given to economic history education in the Anglo-Saxon realm was attributed to the fact that especially those who lectured at universities and departments providing education in a foreign language had acquired their economics doctoral degrees in the USA. A similar situation was observed at the undergraduate level; although it was not as much as microeconomics in terms of course planning, contents, and textbooks, it was stated that while undergraduate and graduate courses were homogenized, undergraduate and graduate levels were detached from each other. While simplification and static analysis were valid at the undergraduate level, dynamic economics and complex systems loomed large at the graduate level (Eren, 2012: 6).

Education programs were similar in this framework, more specifically, economics education programs in both Turkey and the USA converged. In this study, the textbooks and the course contents are not taken into consideration, it is set out to include not only the mainstream economic perspective but also other approaches in the curriculum into the content that should be presented in the history of economic thought and economic history courses based on a pluralistic approach by demonstrating the development of economics. In this study, the number of universities in Turkey is obtained from the list of state and foundation universities prepared by the Council of Higher Education (CHE). The "Economics" programs of state and foundation universities within the "Faculty of Economics", "Faculty of Economics and Administrative Sciences", "Faculty of Political Sciences", "Faculty of Management Sciences" "Graduate School of Social Sciences" are examined through the information on the webpages of the related faculties and institutes. Since some of these universities provide economics education in a foreign language as well as the native language, both course contents of the same program are investigated, but it is found that no major differences exist among the offered courses. To this end, the evaluation for all faculties and institutes is carried out according to the programs providing education in the native language. 
Table 1. Number of Undergraduate and Graduate Programs in Economics (2020)

\begin{tabular}{|l|c|c|}
\hline & Undergraduate & Graduate \\
\hline State University & 99 & 80 \\
\hline Foundation University & 32 & 21 \\
\hline Total & 131 & 101 \\
\hline
\end{tabular}

As of 2020, there are 203 (124 state, and 79 foundation) universities in Turkey. Among these universities, the undergraduate programs of 99 state universities and 32 foundation universities offering economics education are investigated. The remaining are either those without an economics program because they are technical universities or those with undergraduate programs in economics that cannot be reached. Therefore, a total of 131 universities' undergraduate programs are reached, and the courses offered at the undergraduate level within these programs are examined. It is especially examined whether courses such as the economic history and the history of economic thought are offered as core or elective courses. Besides, the graduate programs in the institutes of social sciences of the same universities are investigated. It is checked whether or not the same courses are offered at the postgraduate level, or whether or not the courses taken at the undergraduate level are continuation courses. A total of 101 (21 foundation and 80 state) universities in Turkey offer economics education at the graduate level.

Since the higher education system in Turkey involves the Bologna (also known as the Common European Higher Education) process, it is required and sufficient for the undergraduate students to successfully complete courses of 240 ECTS credits to graduate, whereas courses of 120 ECTS for the graduate students. The Introduction to Economics, Microeconomics, Macroeconomics, and Mathematical Economics, known as core courses at the undergraduate education in Turkey, are compulsory courses. Besides these basic courses, courses such as the economic history, history of economic thought, and economic sociology are offered as either core or elective courses in the first and second years. The core courses are prerequisites $^{4}$ for the undergraduate and graduate level courses.

\footnotetext{
${ }^{4}$ Prerequisite courses refer to courses that are interconnected at undergraduate and graduate levels: Continuation of the undergraduate microeconomics course as advanced microeconomics at the postgraduate level.
} 
Table 2. Number of Universities Offering the Economic History and the History of Economic Thought Courses

\begin{tabular}{|l|c|c|c|c|}
\hline \multirow{2}{*}{} & \multicolumn{2}{|c|}{ Undergraduate } & \multicolumn{2}{c|}{ Graduate } \\
\cline { 2 - 5 } & State & Foundation & Master's & Doctoral \\
\hline Economic History & 73 & 5 & 20 & 15 \\
\hline History of Economic Thought & 77 & 17 & 41 & 22 \\
\hline
\end{tabular}

Economics History courses at the undergraduate level are lectured in 73 state universities and 14 of these courses ${ }^{5}$ are elective courses, whereas 59 ( 2 of them with the title of General Economic History) are core courses in the program. There are 10 universities $^{6}$ at which the Economic History course is lectured for 2 semesters. Besides these courses, the following core courses are also being lectured compulsorily; The Economic History and Society, Evolution of Economics, Economic Society and Civilization, Evolution of Economic Civilizations, Economy-Society, and Civilization, and Social and Economic History I-II. The following are offered as elective courses; Studies on Economic History, History of Economic Events, Sources and Documents in Economic History, New Approaches in Economic History, History of Capitalism, Evolution of Economic and Social Thought. Nevertheless, the core courses usually belong to the first and second years. After attending these courses for the first two years, the student does not face any other courses related to the economic history. It is uncertain whether or not the elective courses would be available each semester. Nonetheless, among the state universities, Istanbul University and Marmara University have the Department of Economics Graduate Programs (Master's and Doctoral). The History of Economic Thought is lectured in 77 state universities, as a core course in 70 universities (two semesters in 9 universities), and as an elective course in 7 universities $^{7}$. Besides the History of Economic Thought, courses such as Comparative Economic Systems, Economic Systems, Comparative Economic Doctrines, and Schools of Economics are offered at 42 universities. Only 7 of these courses are core courses, whereas the courses lectured in 35 universities are elective courses.

\footnotetext{
${ }^{5}$ The economic history is lectured at the following 8 universities: Abant İzzet Baysal University, Afyon Kocatepe University, Bandırma 17 Eylül University, Çanakkale 18 Mart University, Muğla Sitkı Koçman University, Nevşehir Hacı Bektaş Veli University, Pamukkale University, Yalova University. The European Economic History course is offered at 4 universities such as Hakkâri University, Karamanoğlu Mehmet Bey University, METU and Boğaziçi University, whereas the World Economic History course is included in the curricula of 2 universities such as Balıkesir University and Trakya University. These courses are also considered as the Economic History course.

${ }^{6}$ Akdeniz University, Amasya University, Dokuz Eylül University, Eskişehir Osmangazi University, Hacettepe University, Hakkâri University, Harran University, Ankara Hacı Bayram Veli University, Abant İzzet Baysal University, 19 Mayıs University.

${ }^{7}$ Yıldırım Beyazıt University, Osmaniye Korkut Ata University, Niğde Ömer Halisdemir University, Mardin Artuklu University, Çanakkale 18 Mart University, Alanya Alaattin Keykubat University, Adiyaman U0niversity.
} 
Table 3. Number of Universities with Economics Undergraduate Programs including the Economic History and the History of Economic Thought as Elective/Core Courses

\begin{tabular}{|l|c|c|c|c|}
\hline & \multicolumn{2}{|c|}{ Economic History } & \multicolumn{2}{c|}{ History of Economic Thought } \\
\hline & Elective & Core & Elective & Core \\
\hline State University & 14 & 59 & 7 & 70 \\
\hline Foundation University & 3 & 2 & 2 & 15 \\
\hline Total & 17 & 61 & 9 & 85 \\
\hline
\end{tabular}

At foundation universities, students who attend the Economic History course for one semester cannot take any continuation course throughout the remaining semesters of their undergraduate education. Among the universities under examination, Economic History is lectured at 2 universities as a core course, and 3 universities as an elective course. The History of Economic Thought course, however, is taught as a core course at 15 universities, and as an elective course in 2 universities. It is seen that foundation universities devote more time to applied training in the industry, especially in their senior classes. Therefore, an economics education with more technical content is encountered. In this sense, foundation universities, in general, provide training that would adapt to changing conditions as required by the global economy and the business world, in an effort to educate economists who can be employed in economic sectors. In this regard, graduate programs are mostly determined as "Economics and Finance", and consist mainly of microeconomics and finance courses. Among the foundation universities, At1lim University is determined as the only foundation university with a Political Economy Doctoral program.

Table 4. Number of Universities with Economics Graduate Programs including the Economic History and the History of Economic Thought (HET) as Elective/Core Courses

\begin{tabular}{|c|c|c|c|c|c|c|c|c|}
\hline & \multicolumn{4}{|c|}{ Master's } & \multicolumn{4}{|c|}{ Doctoral } \\
\hline & Economi & History & & & Econom & History & $\mathbf{H}$ & \\
\hline & Elective & Core & Elective & Core & Elective & Core & Elective & Core \\
\hline State & 19 & - & 38 & - & 15 & - & 22 & - \\
\hline Foundation & 1 & - & 3 & - & - & - & - & - \\
\hline Total & 20 & - & 41 & - & 15 & - & 22 & - \\
\hline
\end{tabular}

Upon considering the graduate education programs presented in Table 4, the Economic History is included in the graduate programs as an elective course in 19 state universities, whereas it is included in the curricula of 15 universities' doctoral programs as an elective course. The History of Economic Thought is an elective course in the curricula of 38 state universities' master's programs, as well as 22 state universities' doctoral programs. One of the foundation universities (Başkent University) offers the Economic History course (with the title 
of Modern Economic History) in its graduate program, whereas 3 universities teach the History of Economic Thought as an elective course in their graduate program.

\section{Conclusions}

It is seen that the criticism towards economics education has increased in recent years. The method used by the neoclassical economic theory, which has a predominant position in economics education, underlies these criticisms in explaining economic problems. Neoclassical economics defines economics only as a science of "fulfilling unlimited needs with scarce resources", and an analysis is performed on the concepts such as scarce resources, unlimited needs, opportunity cost, rationality, marginal benefit/cost/product, etc. The methodology of this analysis is based on prevalently used mathematical analysis and abstraction.

Once the economics curriculum is established on the basis of this analysis, courses such as economic history, history of economic thought, economic sociology, and economic philosophy cannot gain enough place in the curriculum. The fact that these courses do not have enough place in the curriculum breaks the link between economics and other social sciences such as sociology, history, psychology, philosophy, and ethics, hence, turns economics into a mathematical state. Notwithstanding, economics is closely connected with disciplines such as sociology, history, psychology, philosophy, and ethics. The discipline of economics, which examines the interaction between economy and society on the basis of interpersonal relationships, necessarily involves sociological, historical, philosophical, cultural, and moral aspects. Moreover, moral judgments and ideologies spread throughout economic thought and affect the selected topics, the used assumptions, and the performed economic analysis (Klamer, 1984; Dow, 1992; Hill \& Myatt, 2017). In this context, courses such as economic history, history of economic thought, economic sociology, economic philosophy, and economic psychology offer a wider perspective within the framework of both the "human" comprehension and the "economy" approach.

Therefore, there is a need for a pluralist economics education that includes different schools of economic thought in the curriculum, which does not envision the economy as "fulfilling unlimited needs with scarce resources" and emphasizes that human-beings are sociological and cultural entities by not only concentrating on the "economic" aspect of human-beings. For this purpose, it is aimed at determining the share of the Economic History and History of Economic Thought courses in the undergraduate and graduate curriculum of economics programs offered by the universities established in Turkey. Out of 203 universities, the curriculum of 131 
universities are reached, and the course content of $65 \%$ of the universities with economics programs is examined.

The undergraduate curricula of 131 (99 state and 32 foundation) universities offering economics education in Turkey are reached, and it is investigated whether the courses with sociological, historical, and philosophical content including the economic history and history of economic thought are lectured as core or elective courses in Turkey. Furthermore, it is examined whether the same courses are offered at the graduate level or whether the courses taken at the undergraduate level are prerequisites within the social sciences institutes of the same universities.

At the undergraduate level, the Economics History course is included in the curricula of totally 78 (73 state and 5 foundation) universities, whereas the History of Economic Thought course is included in the curricula of a totally 94 (77 state and 17 foundation) universities. These courses are mostly core courses, but since these courses usually belong to the first and second year, the students do not encounter any other courses on the economic history and history of economic thought after taking these courses for the first two years. This is particularly prominent in foundation universities where a market-oriented curriculum prevails. It is uncertain whether or not the elective courses are available each semester.

At the graduate level, the Departments of the Economic History and Political Economy are present at only two universities. In other universities, the economic history (master's and doctoral programs at 34 universities) and history of economic thought (master's and doctoral programs at 60 universities) are included in the curricula as elective courses.

Consequently, it is determined that the economic history and the history of economic thought courses cover a limited place in the economics curricula of both state and foundation universities. These courses are offered merely as elective courses in the first or second year and are limited to only one semester. The same applies to the graduate education process. In this case, it is indicated that the economics education in Turkey, where a curriculum that is highly influenced by neo-classical economic theory prevails, has been planned according to the standardization that was initiated all over the world including the USA, especially after the Second World War. 


\section{REFERENCES}

Anderson, G., D. Benjamin, \& M. A. Fuss. 1994. The determinants of success in university introductory economics courses. The Journal of Economic Education 25 (4): 99-119.

Aydın, Y. 2016. Post otistik iktisat: İktisat eğitimi ve neoklasik iktisat eleştirisi [Post-autistic economics: Criticism of neoclassical economics and economics education]. Selçuk Üniversitesi Sosyal Bilimler Enstitüsü Dergisi 35: 35-47.

Aysan, A. F., \& M. F. Ulu. 2013. Küresel kriz, iktisat tarihi ve makroiktisat metodolojisi açışından bir kazanç olabilir mi? [Could economic crisis be a advantage for the methodology of economic history and macroeconomics?]. İktisat ve Toplum 20: 5-10.

Aysan A. F., Y. S. Hacıhasanoğlu, G. İ. Kara, \& A. Suner. 2006. Önde gelen iktisat doktora programlarında temel makro iktisat eğitimi [Graduate macroeconomics education in leading Ph.d programs in economics]. Research Report of Boğaziçi University, No: Iss/Ec-200-15. Accessed March 18, 2020. http://ideas.econ.boun.edu.tr/content/wp/ISS_EC_06_15.pdf.

Barone, C. A. 1991. Contending perspectives: Curricular reform in economics. The Journal of Economic Education 22 (1): 15-26.

Blaug, M. 1998. The problems with formalism. Challenge, Taylor \& Francis Journals 41 (3): 35-45. doi: 10.1080/05775132.1998.11472031.

Blaug, M. 2001. No History of Ideas, Please, We're Economists. Journal of Economic Perspectives, 15 (1): 145 164.

Blaug, M. 2003. The formalist revolution of the 1950's. Journal of the History of Economic Thought 25 (2): 145 156. doi: 10.1080/1042771032000083309.

Brückner, S., M. Förster, O. Zlatkin-Troitschanskaia, \& W. B. Walstad. 2015. Effects of prior economic education, native language, and gender on economic knowledge of first-year students in higher education. A comparative study between Germany and the USA. Studies in Higher Education 40 (3): 437-453. doi: 10.1080/03075079.2015.1004235.

Boot, H. M. 1997. Special report: Teaching economic history at Australian universities. Australian Economic History Review 37 (2): 158-164. doi: 10.1111/aehr.372005.

Caldwell, B. 2013. Of positivism and the history of economic thought. Southern Economic Journal 79 (4): 753 67. doi: 10.4284/0038-4038-2012.274.

CEE (Council for Economic Education). 2010. Voluntary National Content Standards in Economics. 2nd ed. Council for Economic Education, New York.

Colander, D., R. P. F. Holt, \& J. P. Rosser. 2010. How to win friends and (possibly) influence mainstream economists. Journal of Post Keynesian Economics 32 (3): 397-408.

Cyert, R. M. 1984. Economic education in our schools: A renewed mission. The Journal of Economic Education 15 (4): 261-64.

Douglas, S., \& J. Sulock. 1995. Estimating educational production functions with correction for drops. The Journal of Economic Education 26 (2): 101-112. doi: 10.2307/1183365.

Dow, S. 1992. Postmodernism and economics. In Postmodernism and the social sciences, ed. J. Doherty, E. Graham \& M. Malek, 148-61. New York: Palgrave Macmillan.

Dow, S. 2009. History of thought and methodology in pluralist economics education. International Review of Economics Education 8 (2): 41-57. doi: 10.1016/S1477-3880(15)30069-4.

Durkheim, E. 1956. Education and sociology. Trans. S. D. Fox. New York: Free Press.

Eren, E. 2012. Küresel bunalım, iktisat eğitimi ve yeni iktisat [The global crisis, economics education and new economics]. Discussion Paper, Turkish Economic Association, No. 2012/103. Accessed March 15, 2020. http://www.tek.org.tr/files/disc/dt71.pdf.

Frank, R. H., T., Gilovich, and D. T. Regan. 1993. Does studying economics inhibit cooperation? Journal of Economic Perspectives 7 (2): 159-171. doi: 10.1257/jep.7.2.159.

Frank, R. H., T., Gilovich, \& D. T. Regan. 1996. Do economists make bad citizens? Journal of Economic Perspectives 10 (1): 187-192. doi: 10.1257/jep.10.1.187.

Gayer, T., \& E. R. Weintraub. 2002. Negotiating at the boundary: Patinkin vs. Phillips. History of Political Economy 32 (3): 441-71.

Giddens, A. 1989. Sociology. Cambridge, UK: Polity Press.

Hahn, J., \& K. Jang. 2010. Economic education in Korea: Current status and changes. The Journal of Economic Education 41 (4): 436-47. doi: 10.1080/00220485.2010.51040.

Hill, R., \& T. Myatt. 2010. The economics anti-textbook: A critical thinker's guide to microeconomics. London: Zed Books.

Hyslop-Margison, E. J. 2000. The market economy discourse on education: Interpretation, impact, and resistance. The Alberta Journal of Educational Research XLVI (3): 203-13.

Kern, W. S. 1990. Frank Knight's skeptical view of economic education. The Journal of Economic Education 21 (2): 195-206. 
Kherfi, S. 2008. Economic education in the Middle East: Are the determinants of success in introductory economics any different? The Journal of Economic Education 39 (1): 22-40. doi: 10.3200/JECE.39.1.2240.

Klamer, A. (1984). Conversations with economists. New Jersey: Rowman and Allanheld.

Kuhn, C., O. Zlatkin-Troitschanskaia, S. Brückner, \& H. Saas. 2018. A new video-based tool to enhance teaching economics. International Review of Economics Education 27: 24-33. doi: 0.1016/j.iree.2018.01.007.

Kurmuş, O. 2009. Bir bilim olarak iktisat tarihinin doğuşu [The emergence of economic history as a science]. İstanbul: Yordam Kitap.

Mankiw, G. 2005. Principles of Economics. 2nd. ed. New York: Dryden Press.

Matherly, W. C. 1935. Economic education. Social Science 10 (2): 23-30.

Mcloskey, D. N. 1976. Does the past have useful economics?. Journal of Economic Literature 14 (2): $434-61$.

Mearman, A., S. Berger, and D. Guizzo. 2016. Curriculum reform in UK economics: A critique. Economics Working Paper Series, 1611, Faculty of Business and Law, University of West England, Bristol. Accessed October 18, 2020. https://uwe- repository.worktribe.com/output/905541/curriculum-reform-in-ukeconomics-acritique.

Nelson, R. H. 2001. Economics as religion. From Samuelson to Chicago and beyond. University Park, Penn.: Penn State University Press.

OECD. 2011. Progress report on economics strand. Paper presented at the 6th meeting of the AHELO Group of National Experts, Paris, March 28-29.

Ramsden, D. 2012. Making economics and economists better: The Government Economic Service perspective. In What's the use of economics? Teaching the dismal science after the crisis, ed. D. Coyle, 3-11. London: London Publishing Partnership.

Ruben, E. 2001. İktisat ögrretiminin sorunlar1 [The boundaries of economic teaching]. İktisat Dergisi 415: 35-40.

Santomero, A. M. 2003. Knowledge is power: the importance of economic education. Business Review, Federal Reserve Bank of Philadelphia, Q4: 1-5. Accessed August 28, 2020. https://ideas.repec.org/a/fip/fedpbr/y2003iq4p1-5.html.

Schumpeter, J. A. 1954. History of economic analysis. Taylor \& Francis e-Library.

Seager, H. R. 1893. Economics at Berlin and Vienna. Journal of Political Economy 1 (2): 236-62.

Sent, E. M. 2006. Pleas for pluralism. In Real World Economics: A Post-Autistic Reader, ed. E. Fullbrook, 177184. London: Anthem Press.

Shiller, R. J. 2010. How should the financial crisis Change how we teach economics? The Journal of Economic Education 41 (4): 403-409. doi: 10.1080/00220485.2010.510409.

Stilwell, F. 2006. Four reasons for pluralism in the teaching of economics. Australasian Journal of Economics Education 3 (1\&2): 42-55.

Sunal, S. 2017. Ne yaptığımızı tam olarak biliyor muyuz? [Do we exactly know what we're doing?]. Iktisat ve Toplum 79: 34-40.

Süalp, M. N. 2012. İktisadın, bir bilimsel öğreti alanı olarak, eğitimi [The teaching of economics as a scientific domain]. Discussion Paper, No. 2012/42, Turkish Economic Association, Ankara. Accessed June 4, 2020. https://www.econstor.eu/bitstream/10419/81604/1/71905916X.pdf.

Şimşek, S. \& Ş. Cicioğlu. 2006. İktisat eğitiminde temel sorunlar ve öneriler [Basic problems and suggestions in

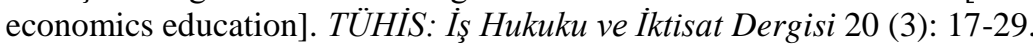

The Members of the PEPS-Economie Students' Association. 2014. The case for pluralism: what French undergraduate economics teaching is all about and how it can be improved. International Journal of Pluralism and Economics Education 5 (4): 385- 400. doi: 10.1504/IJPEE.2014.068320.

Uygur, E. 2012. Küresel bunalım, iktisat politikaları, yöntemleri ve eğitimi [The Global Crisis, Economic Policies, Methods and Education]. Discussion Paper, Turkish Economic Association, No. 2012/99. Accessed March 17, 2020. https://www.econstor.eu/bitstream/10419/81692/1/72918501X.pdf.

Üşür, İ. 2003 Ekonomi Politik: Zarif Mezar Taşları? [Political economy: Elegant sepulchral monuments?], Praksis, 10: 211-238

Yılmaz, A. B., E. S. Tonga, and H. Çakır. 2017. Lisansüstü eğitim öğrencilerinin aldıkları eğitim hakkındaki görüşlerinin değerlendirilmesi [The evaluation of the graduate students' opinions about the education they recieve]. Gazi Üniversitesi Gazi Ĕ̈itim Fakültesi Dergisi 37 (1): 1-45.

Wang, L., Malhotra, D., \& Murnighan, K. 2011. Economics education and greed. Academy of Management Learning \& Education 10 (4): 643-60.

Watts, M. \& G. Lynch. 1989. The principles courses revisited. American Economic Review 79 (2): 236-241.

Wunder, T. A., T. Kemp, \& S. England. 2009. Fact based economic education. Journal of Economic Issues 43 (2): 467-75. 